pendicular period. Halsall, however, four miles from Southport, possesses a fine parish church, largely of fifteenth century date, which will be visited, and the church at Ormskirk is unique in England in possessing a western tower and spire standing side by side. Sefton church is a late sixteenth century building, with remains of earlier work in parts, and has some good interior woodwork. At Burscough, eight miles distant, are the remains of an Augustinian priory, which in its day was one of the most considerable religious houses in Lancashire.

Carr House, at Hoole, a brick building erected in $161_{3}$, is reputed to be the house in which Jeremiah Horrocks observed the transit of Venus in 1639, and Hoole Church, though without architectural merit of any kind, is interesting as the chapel at which Horrocks officiated. There are the remains of a large number of wayside crosses in this part of Lancashire, an excellent specimen standing in Scarisbrick Park, about four miles from Southport.

Lathom is the scene of the famous siege of Lathom House by the Parliamentary forces in 1644 , where Charlotte de la Tremouille, Countess of Derby, made her famous defence. She is buried along with the Earl in the neighbouring church of Ormskirk. Old Lathom House has given place to a classic mansion erected in 1724-34 from the designs of Leoni. Scarisbrick Hall is another old Lancashire mansion that has been rebuilt, the modern house, designed by Augustus Welby Pugin, being a fine example of the domestic work of the Gothic revival.

All along the coast of Lancashire are evidences of submerged lands, and the interest of the Leasowe coast of the Wirral Peninsula is well known to all those who have inquired into the subject of the alteration in the coast line of the country since Roman, or even Norman, times. An opportunity will be afforded of inspecting the submerged forest at Leasowe, and another submerged forest is to be seen nearer to Southport, at the mouth of the Alt, near Formby.

Of places not falling within the Southport district, but which will be visited by the Association, the antiquarian interest of Chester is too well known to need comment. At Whalley are the remains of a great Cistercian abbey, and Whalley church is a building full of architectural and antiquarian interest from the thirteenth to the sixteenth centuries. It contains the stalls belonging to the abbey church, which has completely disappeared. In the churchyard are three preNorman crosses. Time may allow also of a visit to Mytton church and Little Mytton Hall, which lie between Whalley and Stonyhurst. Stonyhurst itself has some antiquarian interest, the original building being a fine Elizabethan house, now incorporated in the vast college buildings. At Manchester mention must be made of the fifteenth century Chetham Hospital and Library, adjoining the Cathedral.

The archæology of the immediate district of Southport may be described as of local rather than of general interest, but a reference to the volumes of proceedings of the Historic Society of Lancashire and Cheshire, and of the Lancashire and Cheshire Antiquarian Society, which will be found in the Southport Reference Library, will show that antiquarian research is very active in the two counties.

The railway companies will issue return tickets to Southport from the principal stations in the United Kingdom at a fare and a quarter on surrender of the usual voucher issued to members. The tickets will be available from September 8 to September 18 inclusive. The local railway companies will issue return tickets at a fare and a quarter to members during the meeting for short distance journeys.

F. H. Cheetham.

\section{NEW SERUM DEPARTMENT OF THE} JENNER INSTITUTE.

U PON the invitation of Lord Lister and the governing body of the Jenner Institute of Preventive Medicine, a number of distinguished guests inspected, on Friday last, the new laboratories and stables which the institute has recently acquired at Queensberry Lodge, Elstree, Herts.

The removal from the former site at Sudbury, near Harrow, became necessary from the encroachment of the Great Central Railway, and the authorities of the institute were fortunate in acquiring a site which is eminently suitable for carrying on the work of the department. This work consists largely in the preparation and testing of antitoxins, such as diphtheria antitoxin, tetanus antitoxin, and antistreptococcic serum, and in carrying on research work in connection with these, and on questions of immunity.

Certain researches also in comparative pathology can be suitably conducted only under such conditions as exist in a department of this character.

The buildings are on the summit of a small hill, and are surrounded by about twenty-eight acres of meadow land, which is conveniently divided into small fields suitable for pasturing and exercising the horses and other animals, such as goats and sheep, which are used in connection with the work. Queensberry Lodge itself has been retained practically as it was when the estate was acquired by the institute, and is now used for the accommodation of the junior staff, administrative offices, \&c. The bacteriologist-in-charge lives in a separate house. The laboratories, which have been built by the institute from designs by Mr. Paul Waterhouse, are of the most modern type, with papyrolith floors with rounded corners, white glazed adamant walls with a dado of white tiles, and large window space. They are warmed by open fireplaces. There is a good gas and water supply, and the buildings are lit by Welsbach incandescent gas burners. The main ideas in the arrangement of the departments have been to provide separate buildings and isolated rooms for carrying out the different processes for the production and testing of antitoxins, thus avoiding risk of contamination of the serum, and at the same time affording adequate laboratory accommodation for the prosecution of research work. In this connection it has been considered advisable to have several small laboratories for one or two workers where undisturbed work can be carried on rather than large laboratories capable of accommodating a number of workers.

The laboratories comprise :-

A Large Routine Laboratory.-This room is furnished with both side and roof lights, and is fitted with centre and side benches, fume chamber, \&c. It is used for general chemical work, for the filtration of diphtheria toxins, for fitting up apparatus, and for such work as section-cutting and blow-pipe work.

Two Private Research Laboratories.-These rooms are well lighted with a north-east aspect. They are completely equipped as bacteriological laboratories, have low benches for microscopical work, and separate Hearson incubators, shelves for reagents, media, \&c.

The Serum Laboratory.-The windows in this room are of ruby glass so as to ensure a non-actinic light. It is used for the filtration and storing of the various sera, and contains two large ice-safes for that purpose. It is fitted with a work bench which has connections with a watervacuum pump, and is also furnished with a Geryk pump.

The Engine Room is fitted with a gas engine driving a large Runne's centrifugal machine and a disintegrator. There is also a Root's blower, which supplies sterile air to the bottling room. There is a water-pump supplying a vacuum and high-pressure air to the neighbouring rooms. 
The Incubation Room is a small insulated room, the insulation being obtained by its having double walls, the space between which is packed with asbestos. It has two doors forming a small "air-lock" to prevent the inrush of cold air on opening the door. By means of a gas stove and Roux regulator the temperature is maintained at bodyheat. This room is used for the cultivation of the different microorganisms used in connection with the work of the establishment.

The Bottling Room is reserved entirely for filling the employed in the cultivation of the various microorganisms. It is fitted with autoclaves, steam sterilisers, thermostats, \&c. This room communicates with the cultivation room by double doors, through which the flasks can be passed after inoculation, thus avoiding lowering the temperature of the hot room by repeatedly entering it.

The Glass Cleaning Room contains a dry-heat disinfector for sterilising the glass apparatus, and is fitted specially for the purpose of cleaning and sterilising glass apparatus. An Isolated Laboratory stands entirely apart from any other building. It is used for the preparation, filtration, and precipitation of such things as tetanus toxin, \&c., and for the ex a m in ation of small animals.

At a considerable distance from the main laboratories, there is a complete small department with stables for carrying on work in connection with other infectious diseases, in addition to those previously mentioned.

The Animal Houses arę ordinary garden greenhouses which have been adapted and prove excellent for the purpose, as they are easily kept to an even temperature. The largest is used as an experimental animal house for the housing of animals employed in the testing of the sera, toxins, \&c. The roof is covered with vines, which have been retained as affording a shelter from the sun in summer. The two smaller houses are used for breeding purposes. The three houses are heated by a system of hot water pipes.

The Principal Stables form two blocks of buildings about 200 yards from the laboratories. They are al brick, and of the most modern type. There are two

Fic. 1.-Plan of New Laboratories of the Jenner Ins:itute at Elstree, Herts. serum into flasks. The windows are of non-actinic ruby glass, and are air-tight. Before bottling is commenced the room is filled with formalin vapour, which is allowed to remain in the closed room all night. In the morning the formalin vapour is displaced by a current of cold air from the outside of the building, which is blown into the room by the Root's blower in the engine room. This air is sterilised before its entry by passage through a large filter of sterile cotton wool. The current of sterile air is maintained throughout the process of bottling, entering the room through the filter and passing out by an exit in the roof through a cotton-wool filter.

The Culture Medium and Sterilising Room.-This room is used for the preparation and sterilising of the media yards, the first of which is covered by a high glass roof, and opening from this yard is the operating room, where the horses are injected and bled. The stabling consists entirely of loose boxes, which are very well ventilated, and are all of a large size, so that the animals have ample room t) move about freely.

In the vicinity of the operating room is a small isolated room with slate benches, where the blood flasks are allowed to stand, and where the serum is decanted.

In one of the meadows, at a distance from the stables, is a loose box which is used as an isolation box. All new horses here undergo a period of quarantine. There are several other loose boxes in the various meadows, as well as an isolated cow-shed, goat-house, pigeon-house, rabbit-runs, \&c. NO. $175 \mathrm{~S}$, VOL. 68] 